\title{
Development of Government Website Studies in Indonesia within 10 years (2011-2020)
}

\author{
Muhammad Shobaruddin* \\ Ilmu Perpustakaan, FIA \\ Universitas Brawijaya \\ Malang, Indonesia \\ *shobar_fia@ub.ac.id
}

\begin{abstract}
The government website is an electronic-based management information system to assist the government in providing information, providing public services, and enabling online transactions to the public with even better quality. The existence of a local government website (Pemda) is a tangible form of the implementation of E-Government that has been commonly implemented and regulated. The local government website is the first level in the development of E-Government in Indonesia which has a target so that Indonesian people can easily get access to information and local government services. This development was followed by an increase in interest in studying government websites in Indonesia. For this reason, this study identifies articles that discuss Government Websites in Indonesia for the span of 10 years (2011-2020). The method used is literature study. The articles under study are publications from 2011-2020. Articles are collected with the keywords "website", "site", "government". The results showed that many government website research titles were studies related to government efforts to use websites to build relationships or services to the community. The various methods used are quantitative (survey, experimental) and qualitative (descriptive, case study), literature study, and Web Usage Mining (WUM) and User Experience (UX) methods. Various studies show that the performance of government websites in Indonesia is still government centrist. On the other hand, the government's website is informative and of good quality, but it is considered less interactive in the services provided. If it is based on the principles of good governance, most of them have not fulfilled it either. This can be due to the problems faced, including the quality of human resources who manage and website interactivity. Over the years, there has not been any improvement in the performance of government websites because the results show relatively similar deficiencies.
\end{abstract}

Keywords-government website, website quality, website analysis

\section{INTRODUCTION}

Indonesia is an archipelago country consisting of 34 provinces, 412 districts and 93 cities (www.otda.kemendagri.go.id) [1]. Therefore, to convey information in government processes, means of communication between governments, with the business world and the community are needed. Based on Presidential Instruction
(Inpres) No. 3 of 2003 concerning policies on the use of information communication technology and the National Strategy for Egovernment Development which aims to improve the quality of public services effectively, efficiently and transparently, it is clear that the position of the website for the government is one of the strategic means in carrying out government activities [2].

Website is a website or virtual location on the web that has its own internet address [3]. A website can be the result of individual work, or show ownership of an organization. Generally, websites show some special topics, or specific interests that the owner represents. A website can contain hyperlinks that link to other websites. Web pages can be viewed or accessed via computer networks and the internet, with a variety of devices such as personal computers, laptops, PDAs or cellular phones [4]. Website is a communication tool which serves as a service medium. Unlike a broadcast medium that works based on the principle of "one message for all circles", a website's service medium must be able to serve a number of specific needs from various groups [5].

The existence of a website can provide many benefits in delivering information. The website can also provide a more complete picture of the activities, services and potential of the organization / institution concerned. With these more complete facilities, it allows the website to offer real time services, faster information retrieval and service offerings, where this option is not available in traditional services [6].

Website is one of the media for publication of information which has its own charm that must be considered by the manager. There are several criteria that must be considered on the website so that it is attractive and users want to access it on an ongoing basis, such as how users search for information through the local government website, what is the target, the message conveyed must have added value (value added).

The government website is an electronic-based management information system to assist the government in providing information, providing public services, and enabling online transactions to the public with even better quality. Actually, e-government does not always take the form of the 
use of the internet and websites, but includes all the uses of various electronic media in government administration. However, the website in its development has become a more popular media than other media uses.

The popularity of the website even often obscures the meaning of e-government itself, as if e-government is synonymous with websites (tools), not as a new reciprocal relationship management system between the government and its various stakeholders (ends) through the development of information technology-based media.

The existence of a local government website (Pemda) is a tangible form of the implementation of E-Government that has been commonly implemented and regulated. The local government website is the first level in the development of EGovernment in Indonesia which has a target so that the Indonesian people can easily get access to information and local government services, and participate in the development of democracy in Indonesia using the internet media [7].

Increasing government services in the form of websites has also increased interest in website studies. During its development, a study will become more specific and the topic of discussion will develop. For this reason, this article aims to conduct a journal review of the website for the last 10 years (2011-2020) in order to provide an overview of what is the focus of the study. Thus, developing studies on websites in the future can fill gaps that have not yet received the attention of researchers. In addition, this article is expected to help website managers to get the references they need.

\section{LITERATURE REVIEW}

A website is said to be of quality if it meets the following aspects:

\section{A. Features}

According to Kominfo 2007, quality standards in the form of egoverment realization, in the form of a website, must have a minimum content as follows:

- At a Glance, briefly explains the existence of the Regional Government concerned (history, regional motto, symbol and symbolic meaning, location in the form of a map, vision and mission)

- Local Government, explaining the organizational structure in the region concerned.

- Geography, describes, among other things, topography, demography, weather and climate, social and economy.

- Map of areas and resources, presenting the administrative boundaries of the region, as well as the resources owned by the region concerned in the form of a resource map.

- Regional regulations or policies, explaining the regional regulations that have been issued by the relevant regional government.
- Guest book and news, a place to receive input from users of the relevant local government website.

\section{B. Transparency}

Transparency is one of the principles of Good Governance. Pasaribu [8] states that transparency is built on the basis of freedom to obtain information needed by the community. This means that information relating to the public interest can be obtained directly by those in need. Transparency is the principle that guarantees access or freedom for everyone to obtain information about government administration, namely information about policies, the process of making and implementing them, and the results achieved.

\section{Accountability}

The government, both central and regional, must be able to become the subject of information givers in the context of fulfilling public rights, namely the right to know, the right to be informed, and the right to have their aspirations heard. Annisaningrum [9] states that accountability is to account for the management of resources and the implementation of policies entrusted to the reporting entity in achieving the objectives that have been set in a manner periodic.

\section{Effectiveness and Efficiency}

The quality of a service will have an impact on the achievement of government targets so that it can be said whether a service provided by the government is effective or not.

\section{RESEARCH METHODS}

The articles under study are publications from 2011-2020. Articles are collected with the keywords "website", "site", "government". The article is a publication from an Indonesian publisher journal. There are 20 articles that are downloaded and searched on the Google search engine. The choice of Google with the aim that later readers if they need the article will easily access it. Then, in the process of this research, the article is then reviewed by reading the research objectives, fields of science, and research results. The results of the review will be categorized in tabular form so that they are easy to read. Grouping in the table will facilitate the discussion process.

\section{RESULTS AND DISCUSSION}

The articles that have been categorized will be discussed regarding the title, research objectives, methods, and research results. With the keywords used, the research titles that appear are related to management, evaluation of quality, performance, utilization, effectiveness, and analysis (website, users, factors, and frameworks). Other accompanying words used to show the function of the website are good governance, public services, public information, the Multi Attribute Decision Making Model, public relations, and public relations. From this title, it can be concluded that the focus of research on many government websites is a study that shows the government's 
efforts to use the website to be able to establish relationships or services with the community. The good and bad of the services provided will be the study material that appears in the research results.

The purpose of a study will describe in more detail what is expected to be produced from a study. The majority of research objectives want to determine the quality of government websites and user satisfaction with different measurement standards, namely the principles of good governance, webqual instruments 4.0, accessibility, performance and traffic, Presidential Instruction no. 3 of 2003 concerning policies and national strategies for E-Government development, as well as user perceptions in the form of usability, quality of information, and quality of service interactions. The various standards used can indicate standards that have not been used for further research. For example, the measurement of government websites that are mobile or smartphone friendly, this is because many users access the website using smartphones. Website analysis following user needs also needs to be developed.

The methods used vary according to the research objectives. Both quantitative (survey, experimental) and qualitative (descriptive, case study), literature study, and Web Usage Mining (WUM) and User Experience (UX) methods.

The results show trends in website performance which are described one by one in this paragraph and the next. Research by Prabowo [10] states that the management of government website content still has a government centrist tendency. For citizen centric-based website development, it is necessary to pay attention to simplification of navigation for many features that cannot be accessed, pay attention to text size and column usage on post pages, maximize Search Engine Optimization (SEO), integrate DPRD pages and tourism information, include social networks for sharing on the website and the user interface is made with a community-based approach [11].

Another trend is the presentation of websites that are already informative and of high quality, but are considered less interactive in the services provided. As a research by Prabowo [10] states that several types of website services are less responsive in terms of transparency, responsiveness, effectiveness, efficiency, and accountability in managing website content as a medium for public service. Research by Diana [12] also states that the results of measuring webqual 4.0 show that usability gets a score of 3.92, the quality of information gets a score of 3.00, service interactions get a score of 2.47 , and the overall score is 3.13 with a maximum scale of 4.00. This figure can be interpreted as the usefulness of the website and the information provided is quite good, but interaction in services still needs to be improved. Likewise, the results of research by Warjiyono and Hellyana [13] state that the current Jagalempeni Village website in terms of Usability Quality, Information Quality, and Visual Quality is of good quality, while in terms of Service Interaction Quality it has not been of good quality, due to user satisfaction (user satisfaction) has not been met. Based on this, a form of interactive service review can be developed for future researchers and becomes a concrete suggestion and a reference source for improvements that can be implemented for government website managers.

Another study shows the performance of government websites based on the principles of good governance. The results of Cheisviyanny's [14] research show that the quality of the website in accordance with the principles of good governance in cities in West Sumatra is still low, resulting in users (government, companies, investors and the public) unable to use the website. The results of research by Kanter and Purnama [15] reveal that the principles of good governance such as transparency and accountability can be felt by visitors to the Manado City Government website even though they are not maximized. Research by Yohana and Yazid [16] shows that the use of the Pekanbaru city government website has not been able to realize good governance. The results of this study indicate that the government website needs to optimize its function based on the principles of good governance so that public services can be implemented better.

The website performance is not good because of the problems faced by the manager regarding the management process. Research by Purnama et al. [17] shows that the problems still being faced with the management of the subang.go.id website content are lack of coordination in website management, limited human resources for managing the website, not updating content, unattractive website appearance., low interactivity between website managers and users, as well as lack of public access to utilizing the website, monotonous appearance of the website. This is because it is still separate and there is no coordination in terms of the duties and responsibilities of the website manager. Research by Handayani [18] also states that the inhibiting factor is that not all Depok people can access the Depok City Government website because it is related to educational abilities, as well as the lack of socialization related to several services that can be done on the Depok City Government website.

The problems faced by website managers have an interplay with the performance of the government website itself. Studies to manage these problems can be carried out so that references for improvement efforts can be reproduced. Thus, over time there are developments in studies that really contribute to improving the management and performance of government websites. 


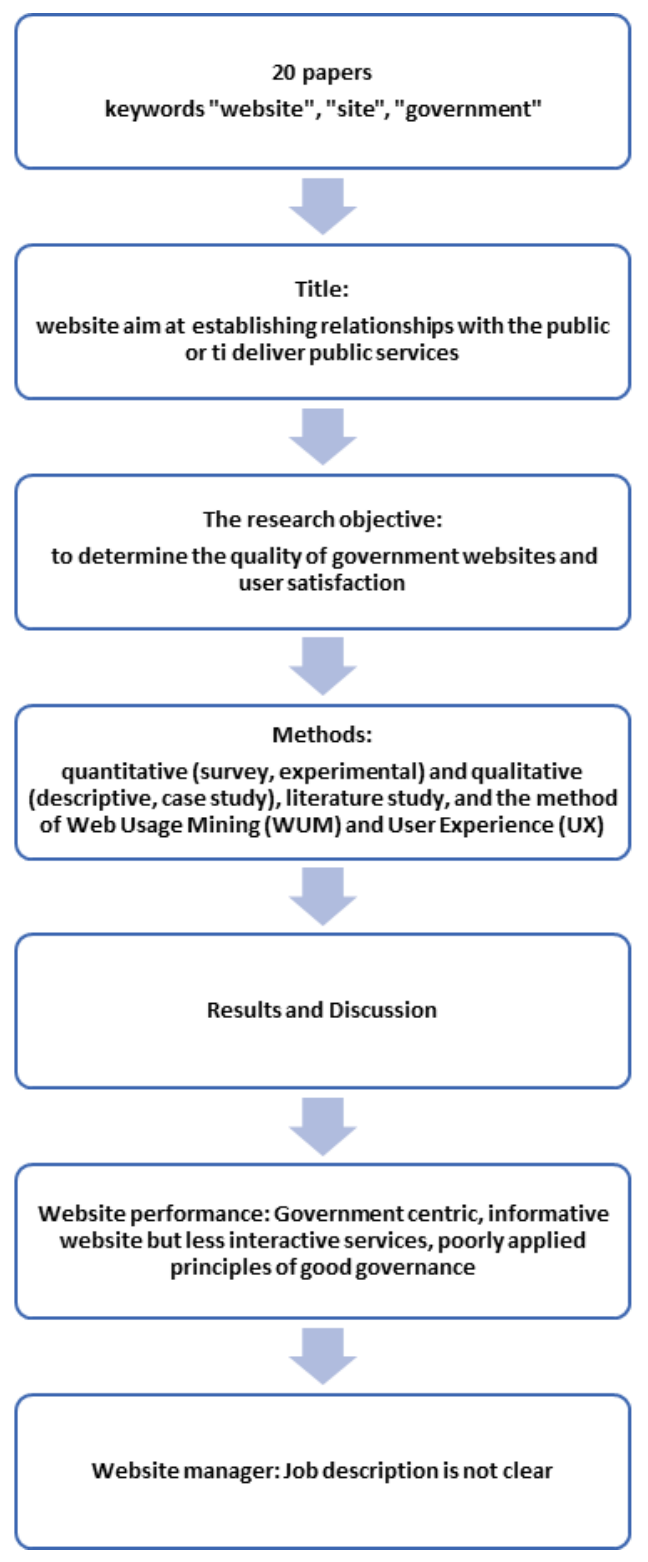

Fig. 1. The trend of studies on government websites in Indonesia.

\section{CONCLUSION}

Publications related to government websites spanning 10 years (2011-2020) show the problems faced by website managers and the performance of government websites in Indonesia. Many government website research titles are studies related to government efforts to use websites to be able to establish relationships or services to the community. The various methods used are quantitative (survey, experimental) and qualitative (descriptive, case study), literature study, and Web Usage Mining (WUM) and User Experience (UX) methods.

The results show that the performance of government websites in Indonesia is still government centric. On the other hand, the government's website is informative and of good quality, but it is considered less interactive in the services provided. If it is based on the principles of good governance, most of them have not fulfilled it either. This can be due to the problems faced, including the quality of human resources who manage and website interactivity. Over the years, there has not been any improvement in the performance of government websites because the results show relatively similar deficiencies.

This research certainly has limitations, such as the possibility that Indonesian publisher articles with closed access have not yet been reviewed. Thus, a similar study for this article as well as with international journal publishers can be carried out to complement the results of this study

\section{REFERENCES}

[1] Direktorat Jenderal Otonomi Daerah. [Online] Retrieved from: www.otda.kemendagri.go.id

[2] F. Masyhur, "Kinerja Website Resmi Pemerintah Provinsi di Indonesia Official Website Performance Local Government in Indonesia," Jurnal Pekommas, vol. 17, no. 1, pp. 9-14, 2014.

[3] Sahid, Teknologi informasi dan komunikasi. Bandung: Yudhistira, 2006.

[4] A. Dipanegara, Langsung jago bikin website. Jakarta: PT. Niaga Swadaya, 2011

[5] R.E. Indrajit, E-Government Strategi Pembangunan dan Pengembangan Sistem Pelayanan Publik Berbasis Teknologi Digital. Yogyakarta: Andi Offset, 2006.

[6] M.D. Anggrahini, C. Rochayanti and E.A. Sosiawan, "Peran humas pemerintah kabupaten Sragen dalam pengelolaan isi informasi website pemda sebagai media communications relations dengan masyarakat," Jurnal Ilmu Komunikasi, vol. 6, no. 2, pp. 145-152, 2014.

[7] Kemenkominfo, Bimbingan Teknis dan Sertifikasi Budaya Dokumentasi Bagi Aparatur Pemerintah.Medan:Kemenkominfo-RI. Jakarta, 2012.

[8] R.B.F. Pasaribu, D. Kowanda and D. Kurniawan," Pengaruh earning management dan mekanisme good corporate governance terhadap pengungkapan corporate social responsibility pada emiten manufaktur di Bursa Efek Indonesia," Jurnal Riset Manajemen dan Bisnis, vol. 10, no. 2, pp. 97-121, 2015 .

[9] Annisaningrum, "Akuntabilitas dan transparansi dalam laporan keuangan," Jurnal Ekonomi, 2010.

[10] G.A. Prabowo, "engelolaan Konten Website Pemerintah Kota Yogyakarta Sebagai Media Pelayanan Publik,” Dialogia: Jurnal Studi Islam dan Sosial, vol. 16, no. 1, pp. 118-137, 2019.

[11] H. Ristiawan, "Analisis user website pemerintah untuk pengembangan website berbasis citizen centric," Jurnal Teknologi Informasi dan Komunikasi, vol. 4, no. 2, pp. 122-135, 2015.

[12] D. Diana, "Analisis Website E-government Provinsi Bengkulu Menggunakan Webqual 4.0," Jurnal Informatika Darmajaya, vol. 14, no. 2, pp. 202-212, 2018.

[13] W. Warjiyono and C.M. Hellyana, "Pengukuran Kualitas Website Pemerintah Desa Jagalempeni Menggunakan Metode Webqual 4.0," Jurnal Teknologi Informasi Dan Ilmu Komputer, vol. 5, no. 2, pp. 139, 2018

[14] C. Cheisviyanny, "Analisis Kualitas Website Pemerintah Daerah Kabupaten/Kota di Provinsi Sumatera Barat," Simposium Nasional Keuangan Negara, vol. 1, no. 1, pp. 1087-1104, 2018.

[15] C.H. Kanter and A. Purnama, "Peran Website Pemerintah Kota Manado Dalam Mendukung Terwujudnya Good Governance Role of Manado'S 
Government Website in Supporting," Jurnal Penelitian Komunikasi Dan Opini Publik, vol. 19, no. 3, pp. 197-212, 2015.

[16] N. Yohana and. T.P. Yazid, "Pemanfaatan Website Pemerintah Kota Pekanbaru dalam Mewujudkan Good Governance," Masyarakat Telematika Dan Informasi: Jurnal Penelitian Teknologi Informasi dan Komunikasi, vol. 5, no. 2, pp. 153-168, 2016.
[17] H. Purnama, A. Adnan and A. Prasetio, "Strategi Humas Siber Melalui Pengelolaan Konten Website Pemerintah - Studi Kasus website www. subang. go. id pada Dinas Komunikasi dan Informatika Kabupaten Subang," Jurnal Komunikasi Universitas Garut: Hasil Pemikiran dan Penelitian, vol. 2, no, 2, pp. 19-25, 2019.

[18] N. Handayani, "Efektivitas Website Dalam Pelayanan Elektronik Pemerintah Kota Depok," SWATANTRA, vol. 15, no. 1, 2017. 